\title{
Preliminary phytochemical, microscopic analysis and metabolite profiling of Phoenix pusilla root
}

\author{
Anuradha Pradeep*, S. Vijaya Bharathi, M. Syed Ali \\ Mohamed Sathak College of Arts and Science, Chennai, India.
}

\begin{tabular}{l}
\hline ARTICLE INFO \\
\hline Received on: 08/04/2019 \\
Accepted on: 30/06/2019 \\
Available online: 05/03/2020 \\
\hline Key words: \\
GC-MS, Phoenix pusilla \\
root, phytochemical analysis, \\
microscopic study, shelf-life.
\end{tabular}

\begin{abstract}
Palms are considered as familiar strangers. Various studies reported that the genus Phoenix was mostly cultivated, traditionally used plants as medicine, and also as an ornamental plant. In this present study, preliminary phytochemical analysis, the study of microscopical structures and the chemical constituents of Phoenix pusilla root was evaluated. Transverse Section of $P$. pusilla root was studied by sectioning the two different thickness roots and also powder microscopy was carried out. Non-polar, volatile constituents of crude ethanolic extract of root were analyzed by GC-MS. Primary and secondary metabolites quantification revealed that the carbohydrate content and total phenolics concentration were higher than the other metabolites. The physicochemical analysis showed the moisture content was $3.78 \pm 0.54$, the ash content value was $2.46 \pm 0.95$, and the crude fiber content was higher than protein, fat content. Microscopy study showed the presence of unique tracheids. Metabolite profiling revealed the presence of 96 different constituents and more than 10 found to have biological importance. Pharmacognostic study is an important step of research which reveals about shelf-life of the drug, adulterations, etc.
\end{abstract}

\section{INTRODUCTION}

Phoenix puscilla (PP) commonly known as dwarf date palm was found to grow in lowland areas and ridges (Sankar and Shoba, 2014). All the parts of this plant found to have folklore medicinal value. Ceylon Date Palm is used in the treatment of bladder stones, piles, fevers, dysentery, rectal prolapses, pies, cough, and urinary tract infections. Porridge made from pith is used in the treatment of gonorrhea, gleet, and fractures and is an antidote for snake bites. Seeds are used as vermifuge with cow milk. Pith is used in the treatment of gonorrhea, gleet, and fractures, which also acts as an antidote for snake bite. Roots are antibacterial and used as a disposable toothbrush (http://www.asia-medicinalplants.info/phoenix-pusilla-gaertn/). Roots of PP are fibrous which anchors the palm strongly to the soil. The leaves are woven into ornamental baskets, sleeping mats, and pouches. The split petioles are used for making baskets. An edible starch is obtained from the stems in times of food shortage.

\section{"Corresponding Author}

Anuradha Pradeep, Mohamed Sathak College of Arts and Science, Chennai, India.E-mail: vanuradha.2003@gmail.com
The leaves are used locally for making baskets, mats, etc. An edible starch is obtained from the trunk. It is used in times of scarcity. The leaves are woven into ornamental baskets, sleeping mats, and pouches. The split petioles are used for making baskets (Sudhersan, 2004).

Drug standardization studies have become a vital part of pharmacognostic studies because this study gives the exact information (macroscopic, microscopic, physiochemical parameters, etc.) of plants. The crude drug has to be evaluated to analyze the biochemical changes, any defect raised during storage and the adulteration. The microscopic analysis utilizes various techniques to check the presence or absence of hairs (trichomes), oil glands, canals, particular cell types, seed or pollen morphology, and vascular traces (Lachumy et al., 2012). Microscopic evaluation includes qualitative and quantitative observations. Qualitative evaluation comprises transverse and longitudinal section of plant parts with or without staining. Quantitative microscopy gives information about the vein number, stomatal number, palisade ratio, etc. Standardization of drugs is an important study which reveals the adulteration and contamination in the herbal preparation (Alamgir, 2017). Importance of the microscopic study of plants 
is to identify and differentiate the plants that resemble the same (Vidya Shriram Patil et al., 2016).

$\mathrm{GC}-\mathrm{MS}$ is the technique used to identify the nonpolar, volatile compounds (Nishaa et al., 2013). GC-MS is utilized in many fields of research including food science, environmental analysis, explosives investigation, unknown sample identification, etc. (Hussain and Maqbool, 2014). Ethnobotanical survey of various places shows that the PP have habitat commonly in southern India (Eswari et al., 2017; Rekha et al., 2013). Xenic and metaxenic study of PP showed that the pollen of PP fertilizes date palm as like pollen of date palm and significant difference were seen in the fruits and seeds developed (Sudhersan et al., 2010). Fruits and roots of P. puscilla were reported to have pharmacological application in traditional medicine. Hence, in this present study, microscopical and metabolite analysis is done to authenticate the structural features and to identify the active constituents present in the extract.

\section{MATERIALS AND METHODS}

\section{Sample preparation}

Roots of PP were collected, authenticated, dried, and ethanol extract (PPE) was prepared using Soxhlet apparatus (Jiji et al., 2016). Briefly, $50 \mathrm{~g}$ of dried Phoenix pusilla (PP) root powder was extracted with ethanol (PPE) by Soxhlet method for 12 hours. The extracts were evaporated, concentrated, and stored.

\section{Organoleptic evaluation}

Sensory screenable parameters like color, odor, taste, size, and shape of the PP root sample were evaluated (Mondal et al., 2013).

\section{Physicochemical evaluations}

Proximate analysis (Moisture content, ash content, crude protein fiber, and fat content) and extractive value were done using the method of Association of official analytical chemist (AOAC Guidelines, 2016). For the determination of extractive value, $1 \mathrm{~g}$ of the root powder is soaked in $100 \mathrm{ml}$ of each solvent, namely, Alcohol, water, and ether and left for 24 hours with frequent shaking. Then, the suspension is filtered and the filtrate is evaporated, dried, and weighed.

\section{Determination of physicochemical characteristics}

Physical characteristics of the test sample were determined which includes bulk density, tapped density, compressibility index, $\mathrm{pH}$, and Hausner ratio that indicate the flow properties of the drug (Bahuguna et al., 2014). The presence of bitterness value, swelling index, and foaming index was done. The pharmacological activity of the drug has been applied to evaluate and standardize the drug (WHO Guidelines; Tarunkumar, 2013)

\section{Heavy metal analysis}

Samples were tested for the presence of heavy metals like arsenic, cadmium, chromium, lead, and mercury (Banares, 2015; Gilreath and Esmarch, 1954).

\section{Fluorescence analysis}

The root dry powder was treated with various solvents (Table 6) and was then observed under UV/visible chamber (Kumar et al., 2013).

\section{Quantitative determination of primary metabolites and secondary metabolites}

The quantitative determination of primary metabolites, such as carbohydrates, protein, total chlorophyll content, and lipid content was evaluated by various methods (Deshmukh et al., 2018; Laveena et al., 2017) and secondary metabolites such as total phenolics, tannins, and total flavonoid were also determined (Shibu and Dhanam, 2015).

\section{Transverse section of roots}

Roots of two different thicknesses were studied. Roots were collected, dried, and fixed in FAA (Formalin-5 ml + acetic acid-5 $\mathrm{ml}+70 \%$ ethanol). After 24 hours of fixing, the specimens were dehydrated with graded series of butanol and filtered by adding paraffin wax. Then, the specimen was sectioned with a microtome to the thickness of $10-12 \mu \mathrm{m}$. The sections were stained with toluidine blue, Safranin, and fast green (Azwanida, 2015).

\section{Powdered microscopy}

Shade-dried roots were finely powdered, a little amount was placed on a slide, and three drops of chloral hydrate were added, then covered with a cover slip and observed under a microscope (Akbar et al., 2014).

\section{GC-MS analysis}

One milliliter of ethanolic extract of the sample was subjected to GC-MS to analyze the chemical composition. GC-MS was carried out using normal phase C18 silica column by maintaining the oven temperature at $60^{\circ}$, injection temperature at $250^{\circ}$, and the pressure maintained at $56.7 \mathrm{kPa}$. Mass spectrum was interpreted using National Institute Standard and Technology library (Patel et al., 2017).

\section{RESULTS AND DISCUSSION}

Therapeutic efficacy of medicinal plants depends upon the quality and quantity of chemical constituents. Pharmacognostic studies ensure plant identity, lays down standardization parameters which will help and prevent adulterations (Chanda, 2014). Among the primary metabolites, carbohydrates were high than the remaining and the lipid concentration was found to be 0.43 $\pm 0.08 \mathrm{mg} / \mathrm{g} \mathrm{dw}$ which was very low than the other primary phytoconstituents (Table 1).

Table 1. Quantification of primary metabolites.

\begin{tabular}{clc}
\hline S. No & Primary metabolites & Sample weight $(\mathbf{m g} / \mathbf{g ~ d w})$ \\
\hline 1 & Carbohydrates & $14.08 \pm 0.21$ \\
2 & Chlorophyll & $3.85 \pm 0.11$ \\
3 & Proteins & $2.03 \pm 0.13$ \\
4 & Lipids & $0.43 \pm 0.08$ \\
\hline
\end{tabular}

The values are mean of Triplicate. 
Similarly, secondary metabolites quantification showed that the total flavonoids were $8.21 \pm 0.22 \mathrm{mg} / \mathrm{g} \mathrm{dw}$, tannins concentration was $6.74 \pm 0.24 \mathrm{mg} / \mathrm{g} \mathrm{dw}$, and total phenolics amount was $28.54 \pm 0.16 \mathrm{mg} / \mathrm{g} \mathrm{dw}$ (Table 2). Various studies reported that the phenol compounds have potent antifungal, antiviral, antibacterial activity, anti-aging, skin renewal property, etc. (Dzialo et al., 2016). For isolation of pure compounds, secondary metabolites quantification is important (Geetha and Geetha, 2014).

Organoleptic evaluation revealed that the root was light brown in color, odorless but has a bitter taste (Table 3). The bitter taste may be due to the presence of tannins. Tannins are polyphenols found to have astringent, bitterness property. Tannins are also used in tanning, dyeing, photography, and in refining beer, wine (Ashok, 2012). It was also found that the root was about 2.4$5.3 \mathrm{~cm}$ long and it was rod-shaped. Proximate analysis showed that the moisture content was low, which indicated the long shelf-life nature of the drug. Stability of the drugs depends on the moisture content (Chandel, 2011).

Fiber content was high than the protein and the fat content (Table 4). Total ash content implies that the inorganic content was less. Usually, the total ash content determines the foreign substance and the other adulterations (Ibrahim et al.,

Table 2. Quantification of secondary metabolites.

\begin{tabular}{clc}
\hline S. No & Secondary metabolites & Sample weight $(\mathbf{m g} / \mathbf{g ~ d w})$ \\
\hline 1 & Total phenolics & $28.54 \pm 0.16$ \\
2 & Tannins & $6.74 \pm 0.24$ \\
3 & Total flavonoids & $8.21 \pm 0.22$ \\
\hline
\end{tabular}

The values are mean of Triplicate.

Table 3. Organoleptic features.

\begin{tabular}{cll}
\hline S. No & Organoleptic features & Sample \\
\hline 1 & Color & Light brown \\
2 & Odor & Odorless \\
3 & Taste & Bitter \\
4 & Size & $2.4-5.3 \mathrm{~cm} \mathrm{long}$ \\
5 & Shape & Rod \\
\hline
\end{tabular}

Table 4. Proximate composition.

\begin{tabular}{clc}
\hline S. No & Composition & Sample \% dry weight \\
\hline 1 & Moisture content & $3.78 \pm 0.54$ \\
2 & Ash content & $2.46 \pm 0.95$ \\
3 & Crude protein & $1.34 \pm 0.42$ \\
4 & Crude fiber & $4.08 \pm 0.72$ \\
5 & Fat content & $1.11 \pm 0.30$ \\
\hline
\end{tabular}

The values are mean of Triplicate.

Table 5. Extractive values.

\begin{tabular}{clc}
\hline S. No & Parameters & Sample \\
\hline 1 & Alcohol soluble extractive $\%$ & $15.26 \pm 0.12$ \\
2 & Water soluble extractive \% & $3.15 \pm 0.03$ \\
3 & Ether soluble extractive $\%$ & $4.85 \pm 0.19$ \\
\hline
\end{tabular}

The values are mean of Triplicate.
2012). Extractive values indicated that the more soluble contents were in ethanol with $15.26 \pm 0.12 \%$, which was followed by ether $(4.85 \pm 0.19)$, and water $(3.15 \pm 0.03)$ stands last (Table 5). Higher alcohol soluble index shows that the alcohol would be the better extractive solvent (Ajazuddin and Saraf, 2010).

Bulk density of the test sample was $0.013 \mathrm{~g} / \mathrm{ml}$, whereas tapped density was found to be $0.783 \mathrm{~g} / \mathrm{ml}$. The compressibility index, Hausner ratio, and $\mathrm{pH}$ obtained were $18.033 \%, 2.803$, and 6 , respectively (Table 6). Foaming index was not found and bitterness value was 0.135 (Table 6). The heavy metals were not present in the test sample which indicates that the sample was in pure form which can be used for further analysis (Table 7).

Fluorescent analysis showed varied colors, such as light brown, dark brown, yellow, pink, violet, etc., on treating with different solvents. Some substances fluoresce in normal light and others in UV light (Table 8). There are other substances which can be converted to fluoresce (Gayathri and Kiruba, 2015). Authentication of plant materials includes macroscopic, microscopic, chemical analysis, and DNA fingerprinting. Due to recent advancements in technology, the microscopical analysis has become a cheap, easy, and convenient method (Lachumy et al., 2012). Thin root has a thick stellar cylinder surrounded by a wide cortical cylinder. Cortical part is ridged and furrowed deeply to varying degrees. The cortical cylinder includes an outer thick continuous layer of compact small thick-walled cells. Thinner cortex has wide, radially elongated air chambers divided by thin seriate partition filaments. A compact prominent fiber bundle was seen in the partition filaments. Central stellar cylinder was $15 \mathrm{~mm}$ in diameter. It consists of an endodermal layer of small spindle-shaped cells with the inner tangential walls and radial walls. Stellar cylinder

Table 6. Physical characteristics.

\begin{tabular}{lc}
\hline Physical characteristics & Sample \\
\hline Bulk density $(\mathrm{g} / \mathrm{ml})$ & $0.013 \pm 0.061$ \\
Tapped density $(\mathrm{g} / \mathrm{ml})$ & $0.783 \pm 0.132$ \\
Compressibility index $(\%)$ & $18.033 \pm 0.156$ \\
Hausner ratio & $2.803 \pm 0.001$ \\
pH range & 6.0 \\
\hline
\end{tabular}

The values are mean of Triplicate except $\mathrm{pH}$.

Table 7. Pharmacological evaluation.

\begin{tabular}{lc}
\hline Parameters & Sample \\
\hline Bitterness value/g & $0.135 \pm 0.008$ \\
Foaming index & Not found \\
\hline
\end{tabular}

The values are mean of Triplicate.

Table 8. Heavy metal determination.

\begin{tabular}{ll}
\hline Heavy metals & Test sample \\
\hline Arsenic & Negative \\
Cadmium & Negative \\
Chromium & Negative \\
Lead & Negative \\
Mercury & Negative \\
\hline
\end{tabular}


consists of densely distributed wide circular, thin-walled vessels, and the ground tissue with lignified cells. The metaxylem and protoxylem vessels are located along the periphery of the vascular cylinder (Fig. 1). The xylem was within the protoxylem. Phloem was seen in between the metaxylem elements.

Thick root was up to $2.5 \mathrm{~mm}$ in diameter. It has a thick continuous cylinder of the sclerenchymatous cortex. The cortical cylinder is followed by the inner cortex. Major part of the cortex was sclerenchymatous with numerous polygonal air-chambers formed by one or two layers of partition filaments. Dark stained fiber bundles were randomly seen in the partition filament. Fiber bundles consist of compact aggregation of angular thick walled lignified fibers (Fig. 2). The central stele has a typical monocot root structure. On the outer zone of the stele, numerous solitary vessels were seen which were wide with the inner region and narrow towards the endodermal cylinder. The vessels were either circular or ovate in outline and measuring about $15-20 \mathrm{~mm}$ in diameter. Towards the outer zone, smaller metaxylem with narrow protoxylem elements was seen. Phloem elements were wide, compact, and thin walled.

Very long uniformly narrow unique types of tracheids were occasionally seen. Tracheids were $10 \mu \mathrm{m}$ thick. Unique

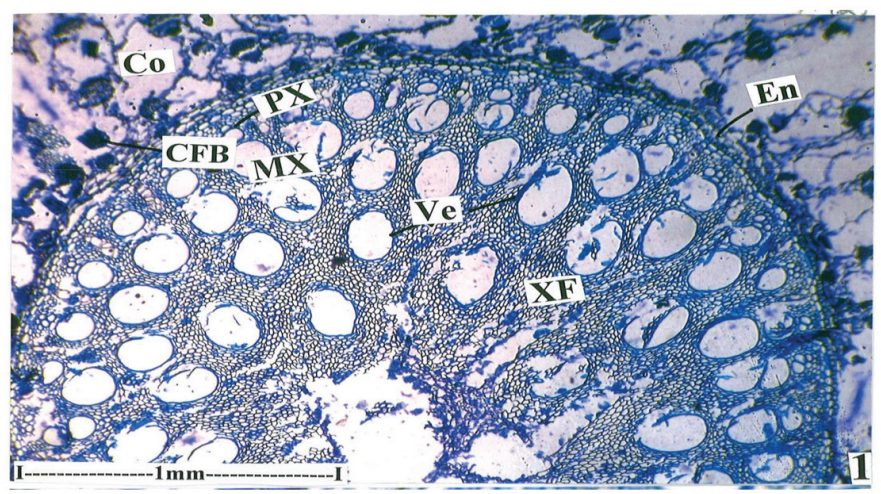

Figure 1. T.S of thin root showing stellar vascular elements. Co $=$ Cortex, CFB $=$ Corticle fibre bundle, $\mathrm{PX}=$ Protoxylem, $\mathrm{MX}=$ Metaxylem, $\mathrm{Ve}=$ Vessels, En $=$ Endodermis, $\mathrm{XF}=$ Xylem fiber

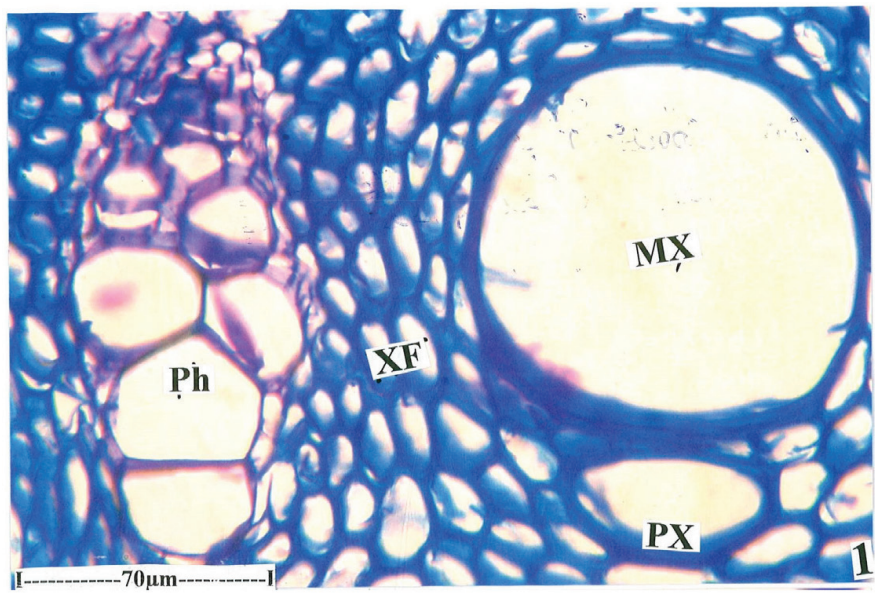

Figure 2. Thick root showing metaxylem and primary xylem in radial arrangement. $\mathrm{Ph}=$ Pholem, $\mathrm{XF}=\mathrm{Xylem}$ fiber, $\mathrm{MX}=$ Metaxylem, $\mathrm{PX}=$ Protoxylem types of tracheid bundles were found to be long, blunt at the ends, and unique in thickness (Fig. 3). Tracheids have dense multiseriate and elliptic horizontal bordered pits (Fig. 4). Tracheids were $500 \mu \mathrm{m}$ long and $60 \mu \mathrm{m}$ wide. Also found abundant libriform fibers which were either narrow or wide. Narrow fibers were thick walled, $550 \mu \mathrm{m}$ long, and $10 \mu \mathrm{m}$ wide. Wide fibers were prominent, wide lumened, and thin walled. Wide fiber was $1.1 \mu \mathrm{m}$ long and $20 \mu \mathrm{m}$ wide. Vessels were either short or barrel-shaped or long and cylindrical. Vessels have very dense multiseriate elliptical opposite and lateral wall bordered pits (Fig. 5). Vessel elements have circular, wide horizontal end wall perforations. Parenchymal cells seen were rectangular or cylindrical in shape.

GC-MS analysis of ethanolic roots (PP) extract results revealed the presence of 96 compounds (Table 9 and Fig. 6). The major constituents belong to fatty acids, sugar, sugar alcohol, phenolics, and organic acids. The compound with high molecular weight was SILIKONFETT SE30; similarly, the compound which showed high retention time (30.775) was dioctyl phthalate. Among the 96 compounds, Xanthosine showed the highest peak area (15.79\%). Xanthosine was found to have wound healing, antibacterial property, and also have application

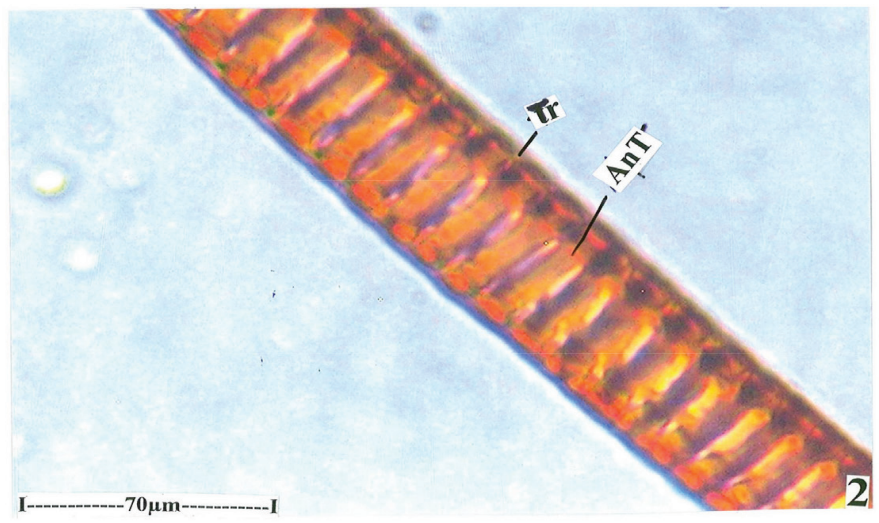

Figure 3. Tracheids showing close annular lateral wall thickening. $\operatorname{Tr}=$ Tracheids, AnT = Annular Tracheid

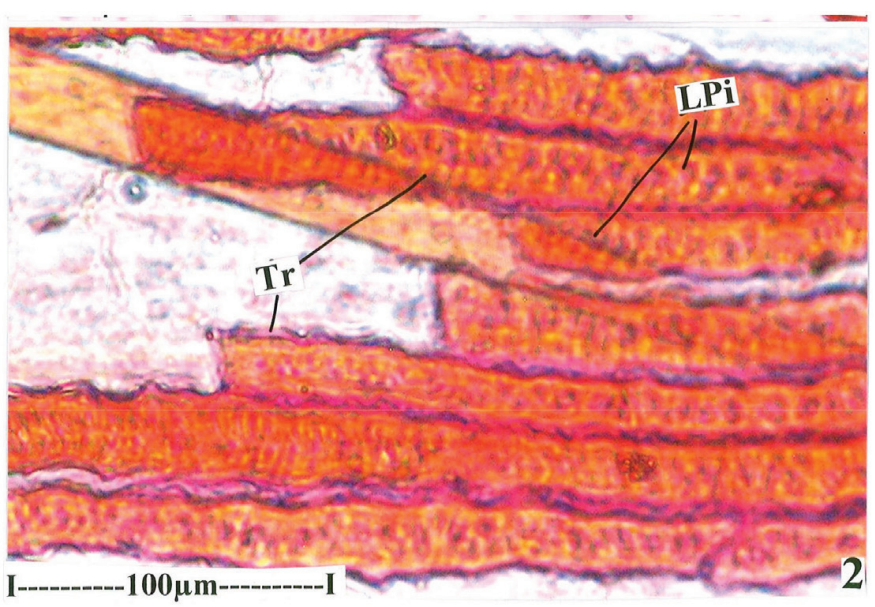

Figure 4. Tracheids showing lateral wall pits. $\mathrm{LPi}=$ Lateral wall pits, $\mathrm{Tr}=$ Tracheids. 


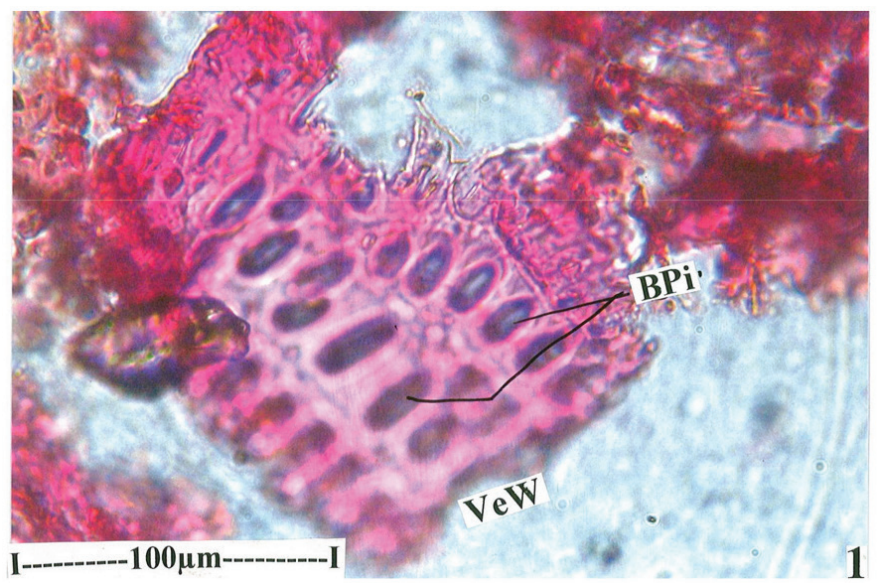

Table 9. Fluorescence analysis.

\begin{tabular}{lll}
\hline Reagents & Sample Visible & Sample UV \\
\hline Powder & Light brown & Dark brown \\
Powder + pet ether & Pink & Black \\
Powder + ethyl acetate & Pink & Dark brown \\
Powder + ethyl acetate: $\mathrm{HCl}(1: 1)$ & Brown & Dark brown \\
Powder + methanol & Pink & Reddish orange \\
Powder + chloroform & Light red & Black \\
Powder + acetone & Pink & Light green \\
Powder $+50 \% \mathrm{H}_{2} \mathrm{SO}_{4}$ & Brown & Black \\
Powder $+50 \% \mathrm{HNO}_{3}$ & Red & Red \\
Powder $+50 \% \mathrm{HCl}_{\text {Powder }+10 \% \mathrm{NaOH}}$ & Yellow & Black \\
\hline & Violet & Black \\
\hline
\end{tabular}

Figure 5. Powder microscopy showing a broken lateral wall of a vessel element. $\mathrm{Bpi}=$ Bordered pits, $\mathrm{VeW}=$ Vessel wall.

Chromatogram SUB PPE D:|data|DEC 2017\SUB PPE.qgd

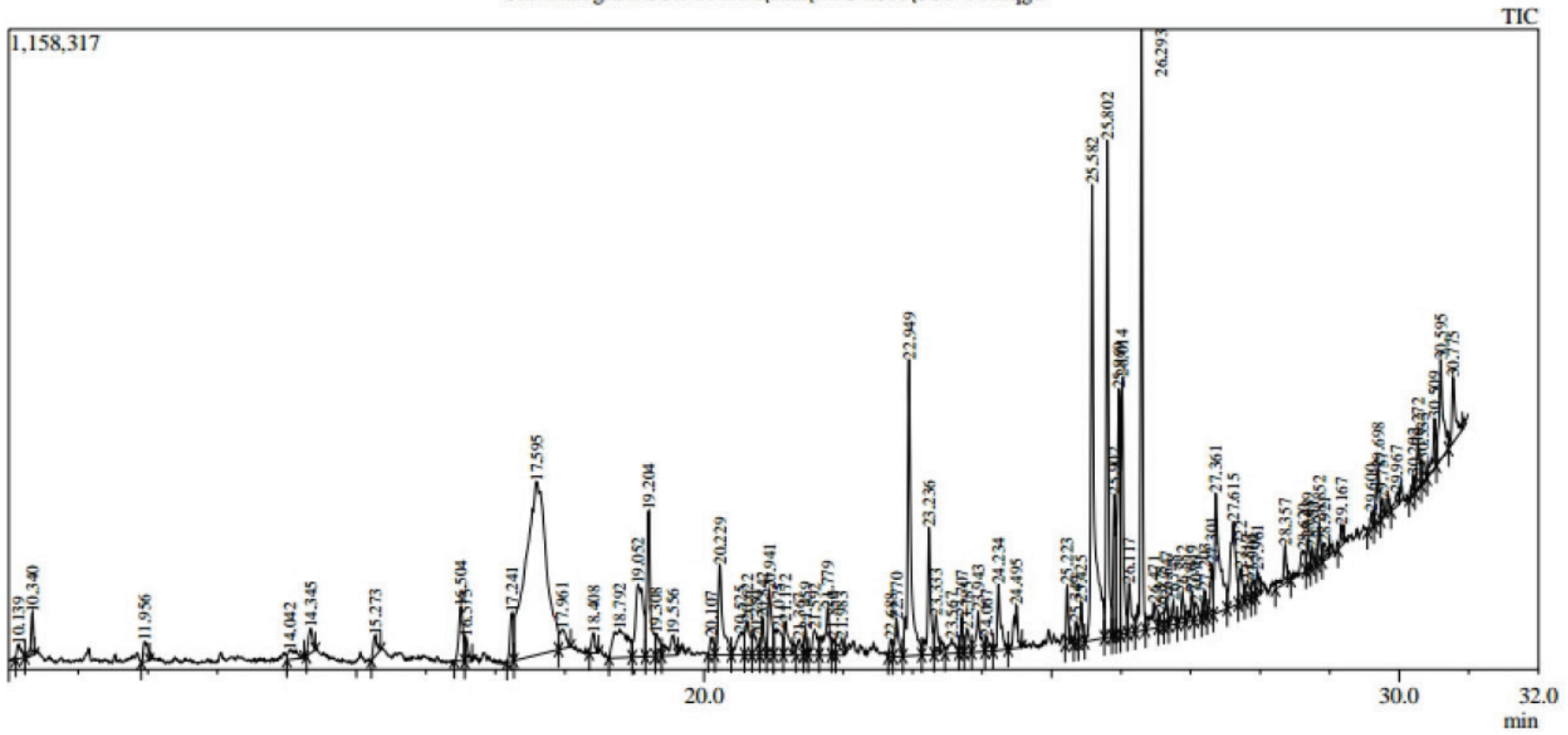

Figure 6. GC-MS compounds identification of P. pusilla.

in stem cell research (Choudhary, 2014). The other compounds having comparatively high peak area were naphthalene $(5.39 \%)$, 9,9- Perhydrobiphenanthryl (4.75\%), 4-((1e)-3-hydroxy-1propenyl)-2-methoxyphenol (4.54\%), 3,6,9-triethyl-3,6,9trimethyl tetracyclo[6.1.0.0 2,4 .0 5,7 ]nonane $(3.12 \%)$, and the remaining showed less than $3 \%$ of peak area. It was identified that the crude extract of PP showed the presence of biologically important compounds like hexanoic acid, Valproic acid, Nipecotic A, Diclofenac sodium, IsochiapinB, hexadeconic acid, and few other compounds. The leaf and fruit pulp of Phoenix sylvestris and P.pusilla were explored through invitro studies for various pharmacological properties. Fatty acid and esters of fatty acids were reported in ethanolic extract of $P$. pusilla fruit
(Antony Thangadurai and Velavan, 2018). Antinoniceptive and neuropharmacological activities of methanolic extract of P. sylvestris fruit was reported (Shahib et al, 2015). Similarly, antioxidant and antibacterial activities were also reported (Sharma et al., 2015). Antioxidant and glycosidase inhibitory potential of mesocarp of $P$. sylvestris fruit was also reported (Susmita Das et al., 2016).

Metabolite profiling by GC-MS will be helpful in planning further analysis through invitro and invivo studies. Thus, the characterization of bioactive compounds by spectral analysis will pave the way to determine the probable role of this unexplored plant parts against several human diseases. 
Table 10. Metabolite profile of PP root crude extract.

\begin{tabular}{|c|c|c|}
\hline S. No & RT Time & Compound \\
\hline 1 & 3.131 & 4-methylpentanoic acid \\
\hline 2 & 3.178 & 3-hydroxybenzylhydrazine \\
\hline 3 & 3.250 & 2-methylpyrazine \\
\hline 4 & 3.417 & 3-(2-methoxy-ethoxymethoxy)-2-methyl-pentan-1-ol \\
\hline 5 & 4.083 & 1-butanol, 2-amino-3-methyl-, \\
\hline 6 & 4.275 & formic acid, pentyl ester \\
\hline 7 & 4.667 & 6-oxabicyclo[3.1.0]hexan-3-one \\
\hline 8 & 5.542 & hexanoic acid \\
\hline 9 & 5.725 & aniline-1-(13)c \\
\hline 10 & 5.792 & 2,4-dihydroxy-2,5-dimethyl-3(2h)-furan-3-one \\
\hline 11 & 7.042 & Benzenemethanol \\
\hline 12 & 7.950 & 3,5-dideutero pyridine-4-carboxylic acid-d1 \\
\hline 13 & 8.050 & Valproic acid \\
\hline 14 & 9.567 & 4-hydroxycyclohexyl acetate \\
\hline 15 & 10.142 & $\begin{array}{l}\text { pyrido[1,2-a]azepine-6,7,8,9-tetracarboxylic acid, } \\
\text { 10-(benzoyloxy)-6,7-dihydro-, tetramethyl ester }\end{array}$ \\
\hline 16 & 10.342 & acetic acid, phenylmethyl ester \\
\hline 17 & 11.958 & 5-hydrxoymethylfurfural \\
\hline 18 & 14.042 & 2,4-dimethylhexan-3-ol \\
\hline 19 & 14.342 & 2-methoxy-4-vinylphenol \\
\hline 20 & 15.275 & 2,6-dimethoxyphenol \\
\hline 21 & 16.500 & pyrimido[1,2-a]azepine, $2,3,4,6,7,8,9,10$-octahydro \\
\hline
\end{tabular}

\section{CONCLUSION}

Pharmacognostic evaluation is important in determining the quality and purity of the drugs. Quantitative parameters of $P$. pusilla root will be helpful in focusing the target metabolite for further medicinal application. The determination of physicochemical parameters revealed the non-toxic nature of the test sample. GC-MS study of $P$. pusilla root showed the existence of pharmacologically active compounds. Among the active compounds, further study on Saponin has to be focused for purification, characterization, and explored for its pharmacological activity through in-vivo studies.

\section{CONFLICT OF INTEREST}

The authors declare that they have no conflict of Interest

\section{REFERENCES}

Ajazuddin, Saraf S. Evaluation of physicochemical and phytochemical properties of Safoof-E-Sana, a Unani polyherbal formulation. Pharmacognosy Res, 2010; 2(5):318-22.

Akbar S, Hanif U, Ali J, Ishtiaq S. Pharmacognostic studies of stem, roots and leaves of Malva parviflora L. Asian Pac J Trop Biomed, 2014; 4(5):410-5.

Alamgir ANM. Microscopy in pharmacognosy, therapeutic use of medicinal plants and their extracts. Pharmacognosy, 2007; 1:497-513.

Antony Thangadurai T, Velavan S. Bioactive compounds in ethanolic extract of Phoenix pusilla fruit using GC-MS technique. J Biol Chem Research, 2018; 35(3):779-84.

Ashok PK, Upadhyay K. Tannins are astringent. J Pharmacogn Phytochem, 2012; 1(3):45-50.

Association of Analytical Communities (AOAC). Official method of Analysis of AOAC, International. 20th edition, 2016.
Azwanida A. A review on the extraction methods use in medicinal plants, Principle, Strength and limitation. Med Aromat Plants, 2015; 54:196; doi:10.4172/2167-0412.

Bahuguna Y, Zaidi S, Kumar N, Rawat K. Standardization of polyherbal marketed formulation Triphala churna. Res and Rev: J Pharmacogn Phytochem, 2014; 2(3):28-35.

Banares B, Ma Lourdes Alvarez C. Detection of the presence and concentration of heavy metals in selected rivers in the province of Samar. Int J Res Granthaalayah, 2015; 3(9):70-86.

Chanda S. Importance of pharmacognostic study of medicinal plants: an overview. J Pharma Phytochem, 2014; 2(5):69-73.

Chandel HS, Pathak AK, Tailang M. Standardization of some herbal antidiabetic drugs in polyherbal formulation. Pharmacognosy Res, 2011;3(1):49-56

Choudhary RK. Mammary stem cells: expansion and animal productivity. J Animal Sci Biotech, 2014; 5:36.

Das S, Acharya J, De B. Metabolite profiling, antioxidant activity, and glycosidase inhibition property of the mesocarp tissue extracts of sugar date palm [Phoenix sylvestris (L.) Roxb.] fruits, Int J Food Properties, 2017; 20:12.

Deshmukh, Madhuri A, Theng. Phytochemical screening, quantitative analysis of primary and secondary metabolites of Acacia arabica Bark. Int J Current Pharma Res, 2018; 10(2):35-7.

Działo M, Mierziak J, Korzun U, Preisner M, Szopa J, Kulma A The potential of plant phenolics in prevention and therapy of skin disorders. Nt J Mol Sci, 2016; 17(160):1-41.

Eswari V, Karthikeyan S, Arumugam M. Survey of medicinal plants in tropical evergreen forest-Kodiakkarai (point calimere). J Sci, 2017; 7(8):273-81.

Gayathri V, Kiruba D. Fluorescence analysis of two medicinal plants-Psidium guajava L and Citrus aurantium. Int J Pharm Sci Res, 2015; 6(3):1279-82.

Geetha TS, Geetha N. Phytochemical screening, quantitative analysis of primary and secondary metabolites of Cymbopogan citratus (DC) stapf. leaves from Kodaikanal hills, Tamilnadu Int J Pharm Tech Res, 2014; 6(2):521-9.

Gilreath and Esmarch S. Qualitative analysis: using semimicro methods. McGraw-Hill Book Company, Inc., New York, NY, 1954.

Hussain, Maqbool K. GC-MS: principle, technique and its application in food science. Int J Curr Sci, 2014; 13:116-26.

Ibrahim JA, Makinde O, Ibekwe NN. Pharmacognostic, physicochemical standardization and phytochemical analysis of leaves of cultivated Crotalaria lachnosema Stapf. J Appl Pharm Sci, 2012; 2(9):067-70.

Jiji KN, Pramod C, Boby S Prasad, Muralidharan P. Evaluation of antidiabetic activity of ethanolic extract of Trema orientalis (L.) Blume Leaves. IOSR J Pharm Bio Sci, 2016; 11(5):7-26.

Kumar M, Mondal P, Borah S, Mahato K. Physico-chemical evaluation, preliminary phytochemical investigation, fluorescence and TLC analysis of leaves of the plant Lasiaspinosa (lour) thwaites. Int J Pharm Pharm, 2013; 5(suppl 2):306-10.

Lachumy SJ, Sasidharan S. The usage of microscopy method for herbal standardizations. Curr Micro Adv Sci Technol, 2012; 2:704-10

Laveena KB, Chandra M. Qualitative and quantitative phytochemical analysis of primary and secondary metabolites of Mussaenda bellila L. from Western Ghats of Karnataka. World J Pharma Res, 2017; 6(16):1155-66.

Mondal P, Kumar M, Das S, Zaman MK. Pharmacognostical characterization of the bark of the plant Plumeria rubra. Int J Pharm Res Dev, 2013; 5(3):59-67.

Nishaa S, Vishnupriya M, Sasikumar JM, Gopalakrishnan VK. Phytochemical screening and GC-MS analysis of ethanolic extract of rhizomes of Marantaa rundinacea L. Res J Pharma Biol Chem Sci, 2013; 4(2):52-9.

Patel J, Reddy V, Kumar GS, Satyasai D, Bajari B. Gas chromatography and mass spectroscopy analysis of bioactive components 
on the leaf extract of Terminalia coriacea: a potential folklore medicinal plant. Int J Green Pharm, 2017; 11(1):S140-3.

Rekha D, Tamil Selvi S, Bharathidasan R, Panneerselvam A, Ilakkiya R, Jayapal R. Study of medicinal plants used from Koothanoallur and Marakkadai, Thiruvarur district of Tamil nadu, India. Hygeia J Drugs Med, 2013; 5(1):164-70.

Sankar V, Shoba FG. Quantitative and qualitative analysis of various phyto-constituents in Phoenix pusilla unripe fruit ethanolic extract. Asian J Pharm Clin Res, 2015; 7(5):216-9.

Shajib MS, Akter S, Ahmed T, Imam MZ. Antinociceptive and Neuropharmacological activities of methanol extract of Phoenix sylvestris fruit pulp. Front Pharmacol, 2015; 6:212.

Sharma DC, Shukla R, Ali J, Sharma S, Bajpai P, Pathak N. Phytochemical evaluation, antioxidant assay, antibacterial activity and determination of cell viability (J774 and THP1 ALPHA Cell lines) of P. sylvestris leaf crude and methanol purified fractions. Excli J, 2016; 15:85-94.

Shibu A, Dhanam S. Phytochemical screening of Caulerpa recemosa collected from Gulf of Mannar, Tamil Nadu. Asian J Biochem Pharm Res, 2015; 5(3):42-5.
Sudhersan C, Jibi Manuel S, Al-Sabah L. Xenic and metaxenic effect of Phoenix pusilla pollen on certain date palm cultivars. Acta Hortic, 2010; 882:297-302

Sudhersan C. Introduction of a multipurpose palm, Phoenix pusilla, in Kuwait. Palms, 2004; 48(4):191-6.

Tarunkumar. Standardization of herbal drugs - a review. Int J Universal Pharm BioSci, 2013; 2(4):7-18.

Patil, Rajput KS, Malpathak NP. Comparative study on morphoanatomy of leaf, stem and root of Boerhaavia diffusa L. (Nyctaginaceae) and its adulterant plants. Braz J Pharm Sci, 2016; 52(3):433-42.

WHO. Quality control methods for herbal materials. WHO, Geneva, Switzerland, 1998.

How to cite this article:

Pradeep A, Bharathi SV, Ali MS. Preliminary phytochemical, microscopic analysis and metabolite profiling of Phoenix pusilla root. J Appl Pharm Sci, 2020; 10(03):128-134. 